\title{
Qualitative and quantitative analysis of phytochemicals of crude extracts of Ageratum conyzoides L. leaves
}

\author{
K. Nusalu Puro, Muslek Uddin Mazumder, P. Khazeo, Rosamund Jyrwa, Nungshioba Jamir, \\ Lalzikpuii Sailo*
}

Department of Pharmacy, Regional Institute of Paramedical and Nursing Sciences, Zemabawk 796017, Mizoram, India

Corresponding author: zikpuii08@gmail.com

\begin{abstract}
Ageratum conyzoides $L$., belonging to the family Asteraceae, is an annual herbaceous plant and is an invasive weed. It contains bioactive compounds that are reported to possess therapeutic properties. The species has been studied widely owing to its biological properties and its potential application in medicine and agriculture. It is used in the treatment of burns and wounds, arthrosis, malaria, asthma, leprosy and dermatitis. It also has insecticidal activity against a range of major pests of field crops. Chromatographic analyses have identified pyrrolizidine alkaloids, phenolic acids, coumarin and polymethoxyflavones. The present study was conducted to determine the qualitative and quantitative properties of the crude extracts of the leaves. Extracts were prepared by using petroleum ether, chloroform and methanol solvents. The yield of extract was calculated for all the three solvents and they are studied for qualitative analysis of phytochemical compounds and quantitative analysis. The qualitative phytochemical tests exhibited the presences of alkaloids, carbohydrates, phenols, tannins, steroids, terpenoids, glycosides, saponins, and amino acid. Quantitative analysis suggests the presence of tannins, alkaloids and phenols in the leaves and this can be utilized for further investigations.
\end{abstract}

Keywords: Ageratum conyzoides L., phytochemical, bioactive, quantitative, tannins.

\section{INTRODUCTION}

Since ancient times, medicinal plants have been used for their healing properties and they remain the fundamental sources of novel biological active compounds (Bearth et al., 2014). Medicinal plants and natural products possessing pharmacological models have been considered as alternative therapy for the treatment of various diseases (Singh et al., 2017). The chemical compounds produced by plants are as a result of normal metabolic activities. These chemical compounds are classified into primary and secondary metabolites, and the secondary metabolites and other chemical constituents contribute to their medicinal value (Varadarajan et al., 2008).

Phytochemicals are non-nutritive plant chemicals that have protective and preventive properties against diseases (Breslin and Andrew, 2017). They are among the secondary metabolites naturally occurring in plants and most often possessing health benefits (Kabera et al., 2014). They play a vital role in the protection of plants as antibacterial, antiviral, antifungal and insecticidal agents (Hajlaoui et al., 2009).

Ageratum conyzoides L. belongs to the family Asteraceae. It is native to Central America and is invasive in Southeast Asia, West Africa, South China and India (Iwu, 2000; Prince and Prabakaram, 2011; Amadi et al., 2012). It is an annual herbaceous plant which grows to approximately one meter in height. The stems and leaves are hairy, the leaves are ovate bearing purple to white flowers (Marks and Nwachuku,1986). The plant grows widely in agricultural land, roadside and is very common in waste places and on ruined sites. It is commonly utilized as folk remedies for the treatment of pneumonia, cure wounds and burns (Durodola, 1977), colic, colds, and fevers, diarrhoea, rheumatism, spasms (Oliveira et al., 1993), have anti-inflammatory, antipyretic, analgesic 
activity (Abena et al.), insecticidal activity (Gbolade et al., 1999), antidysenteric, and antilithic activity (Borthakur and Baruah, 1987). The plant extract is found to possess cardiovascular depressant (Achola et al., 1994) and antioxidant activities (Amal et al., 2010).

The present study investigated the qualitative and quantitative analysis of phytochemicals of crude extracts of $A$. conyzoides leaves.

\section{Materials AND MethodS}

\section{Plant material}

Fresh plants of Ageratum conyzoides L. was collected from Zemabawk, Aizawl, Mizoram, India and authenticated by a taxonomist at the Botanical Survey of India, Shillong, India, vide letter No.BSI/ERC/Tech./Plan Iden./2018/136. A voucher specimen has been deposited in the Department of Pharmacy, RIPANS. Fresh leaves were washed with tap water and then finally with distilled water followed by shade drying at room temperature for 15-20 days. The shade-dried leaves were made into powdered using electrical blender.

\section{Preparation of extract}

The dried leaves powdered were introduced to successive extraction by refluxing in the Soxhlet apparatus using petroleum ether, chloroform and methanol as solvents. About $245 \mathrm{~g}$ of powdered leaves were uniformly packed into the thimble and extracted with the above solvents. The process of extraction continues for 36 hours or till the solvent in the siphon tube become colorless. The extract was taken into sterile beaker and concentrated by evaporating the solvents in water bath. The dried extract was stored in refrigerator for further analysis.

\section{Qualitative phytochemical analysis}

The crude methanolic extract of Ageratum conyzoides L. leaves were screened for phytochemicals such as alka-

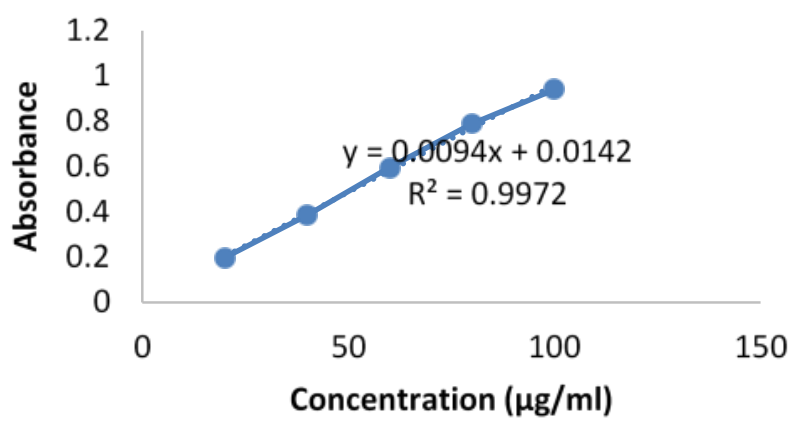

Figure 1: Standard curve for total alkaloidal content. loids (Dragendorff's test, Mayer's test, Wagner's test), carbohydrates (Fehling's test, Benedict's test), phenols and tannins (ferric chloride test, Lead acetate test), flavonoids (Shinoda test, lead acetate test, alkali test), saponins (foam test), triterpenoid (Salkowski's test), glycosides (Liebermann's test, Keller-Kilani test ), steroids, proteins (Millon's test, ninhydrin test) (Aziz, 2015; Yadav and Agarwala, 2011; Thakur, 2018; Santhi and Sengottuvel, 2016).

\section{Quantification of alkaloids}

$1 \mathrm{mg}$ of the crude methanolic extract of $A$. conyzoides leaves was dissolved in dimethyl sulphoxide (DMSO), 1 $\mathrm{ml}$ of $2 \mathrm{~N} \mathrm{HCl}$ was added and allow to filtered. $5 \mathrm{ml}$ each of bromocresol green and phosphate buffer were added to the filtrate and transferred to separating funnel. 1, 2, 3 and $4 \mathrm{ml}$ of chloroform was added to solution mixture by vigorous shaking and collected in $10 \mathrm{ml}$ volumetric flask. Then, the volume of these flasks was diluted to the mark with chloroform. A set of reference standard solutions of atropine $(20,40,60,80$ and $100 \mu \mathrm{g} / \mathrm{ml})$ were prepared in the similar manner as described above. Absorbance for test and standard solutions were determined against the blank at $470 \mathrm{~nm}$ using UV-visible spectrophotometer. The total alkaloid content was expressed as $\mathrm{mg}$ of $\mathrm{AE} / \mathrm{gm}$ of extract (Shamsa et al., 2008; Raob et al., 2016).

\section{Quantification of phenols}

Folin-Ciocalteu spectrophotometric method was used to determined total phenolic content in crude methanolic extract of $A$. conyzoides leaves. $1 \mathrm{ml}$ of extract and 9 $\mathrm{ml}$ of distilled water was taken in $25 \mathrm{ml}$ of volumetric flask, followed by addition of $1 \mathrm{ml}$ of Folin-Ciocalteu phenol reagent and shaken well. After a period of 5 minutes, $10 \mathrm{ml}$ of $7 \%$ sodium carbonate solution was added to the mixture. The volume was made up to $25 \mathrm{ml}$ with distilled

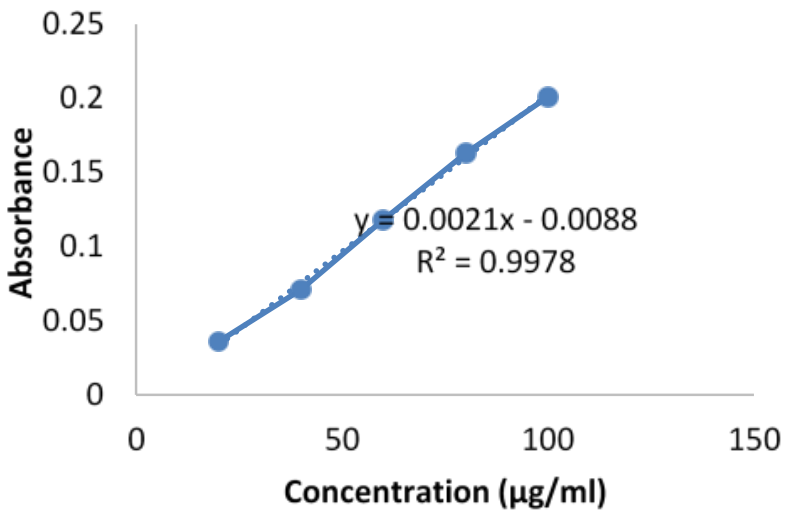

Figure 2: Standard curve for total tannin content. 


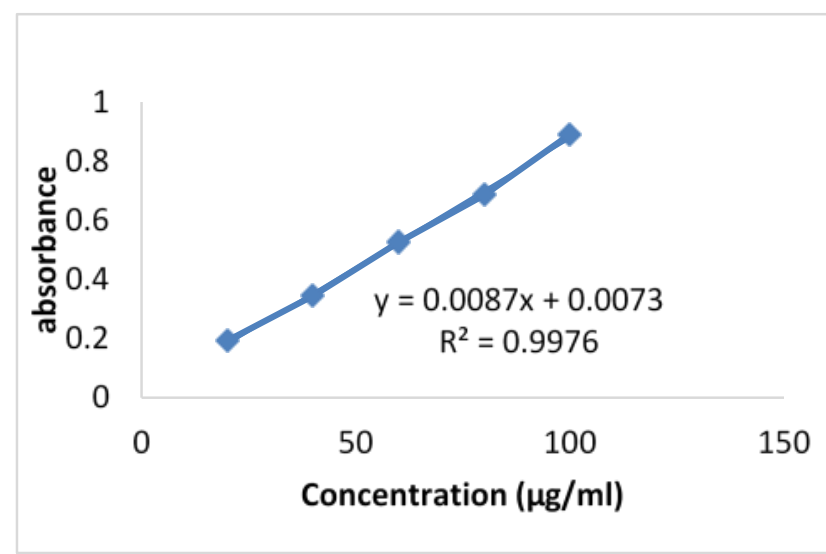

Figure 3: Standard curve for total phenol content.

water. A set of reference standard solutions of gallic acid $(20,40,60,80$ and $100 \mu \mathrm{g} / \mathrm{ml})$ were prepared in the same manner as described above. The prepared test and standard solutions were incubated for 90 minutes at room temperature. The absorbance for test and standard solutions were recorded against blank at $550 \mathrm{~nm}$. The total phenolic content was expressed as $\mathrm{mg}$ of $\mathrm{GAE} / \mathrm{gm}$ of extract (Rasool et al., 2011; Ghasemzadeh et al., 2010; Stankovic, 2011).

\section{Quantification of tannins}

Total tannin content was determined by FolinCiocalteu spectrophotometric method using gallic acid as standard. About $0.1 \mathrm{ml}$ of plant extract and $7.5 \mathrm{ml}$ of distilled water were taken in $10 \mathrm{ml}$ volumetric flask, 0.5 $\mathrm{ml}$ of Folin-Ciocalteu phenol reagent and $1 \mathrm{ml}$ of $35 \%$ Sodium carbonate solution was added. The volume was made up to $10 \mathrm{ml}$ with distilled water. The solution mixture was shaken well and kept aside for 30 minutes at room temperature. A set of standard solutions of gallic acid $(20,40,60,80$ and $100 \mu \mathrm{g} / \mathrm{ml})$ were prepared in the similar manner as mentioned above. The absorbance for test and standard solutions were measured against blank at $725 \mathrm{~nm}$. The total tannin content was expressed in terms of $\mathrm{mg}$ of GAE/gm of extract (Marinova et al., 2005; Singh et al., 2012; Afify et al., 2012; Miean and Mohamed, 2011).

Table 1: Extraction yield of the leaves of Ageratum conyzoides $\mathrm{L}$.

\begin{tabular}{|c|c|c|}
\hline S.No & Extract & Extractive yield (\%) \\
\hline 1 & Petroleum ether & 5.52 \\
\hline 2 & Chloroform & 6.55 \\
\hline 3 & Methanol & 8.39 \\
\hline
\end{tabular}

\section{RESULTS}

\section{Extraction yield}

$245 \mathrm{gm}$ of dried weight of $A$. conyzoides leaves were utilized for extraction using different solvent such as petroleum ether, chloroform and methanol and the extractive yield was summarized in Table 1 .

\section{Qualitative phytochemical analysis}

The qualitative analysis of phytochemicals from crude methanolic extract of $A$. conyzoides leaves was analyzed and showed the presence of several phytoconstituents which are summarized in Table 2 . The results revealed the presence of alkaloids, carbohydrates, phenols and tannins, flavonoids, saponins, triterpenoids, glycosides and steroids.

Table 2: Phytochemicals in the crude of methanolic extract of Ageratum conyzoides L. (+ Present; - Not detected)

\begin{tabular}{|c|c|c|}
\hline S.No & Phytochemicals & Methanolic extract \\
\hline 1 & Alkaloids & + \\
\hline 2 & Carbohydrates & + \\
\hline 3 & Phenols and tannins & + \\
\hline 4 & Flavonoids & + \\
\hline 5 & Saponin & + \\
\hline 6 & Triterpenoids & + \\
\hline 7 & Glycosides & + \\
\hline 8 & Steroids & + \\
\hline 9 & Protiens & - \\
\hline
\end{tabular}

\section{Quantification of phytochemicals}

The quantitative estimation of crude methanolic extract of A. conyzoides leaves was examined for total alkaloids, total tannins and total phenolic content as mentioned in Table 3 . The alkaloid content in plant extract was expressed as atropine equivalent ( $\mathrm{mg}$ of $\mathrm{AE} / \mathrm{g}$ of extract) and was found to be $8.7 \pm 0.2 \mathrm{mg}$ of $A E / g$ of extract. Total phenolic and tannin were estimated using FolinCiocalteu reagent and were expressed as gallic acid equivalent (mg of GAE/g of extract). The total tannin con-

Table 3: Phytochemicals content of plant extract. Each value is the average of three analyses \pm standard deviation

\begin{tabular}{|c|c|c|}
\hline S.No & Phytochemicals & Content $(\mathrm{mg} / \mathrm{g})$ \\
\hline 1 & Alkaloids & $8.7 \pm 0.2$ \\
\hline 2 & Tannins & $108.17 \pm 0.76$ \\
\hline 3 & Phenols & $122.08 \pm 1.91$ \\
\hline
\end{tabular}


tent was estimated to be $108.17 \pm 0.76 \mathrm{mg}$ of $\mathrm{GAE} / \mathrm{g}$ of extract, while that of total phenolic content was examined to be $122.08 \pm 1.91 \mathrm{mg}$ of $\mathrm{GAE} / \mathrm{g}$ of the extract.

\section{DISCUSSION}

When herbs are used for treating certain ailments and disorder, phytochemicals as bioactive compounds are responsible for its medicinal as well as physiological activities (Alabri et al., 2014). Qualitative phytochemical analysis of the present study revealed the presence of alkaloids, carbohydrates, phenols and tannin, flavonoids, saponins, triterpenoids, glycosides and steroids. Alkaloids possess biological properties such as analgesic, antibacterial, antispasmodic activities.

Phenolic compounds show varieties of pharmacological activities such as antiapoptosis, antiaging, anticarcinogen, antiinflammation, antiatherosclerosis and tannins have astringent property. Flavonoids are commonly used natural antioxidant having antimicrobial as well as anticarcinogenic properties. Saponins are characterized by formation of foam with aqueous solution and are known to possess anti-inflammatory activity (Yadav and Agarwala, 2011). Glycosides have the property of cardioactive drug and used for the treatment of cardiovascular disease (Brain et al., 1985). Quantitative estimation of total alkaloid, tannin and phenol revealed that there is significant presence of tannin and phenol in the plant extract while alkaloid are present in lesser amount.

\section{CONCLUSION}

Thus from the present study, the crude methanolic extract of $A$. conyzoides leaves possess different varieties of phytochemicals such as alkaloids, carbohydrates, phenols and tannin, flavonoids, saponins, triterpenoids, glycosides and steroids. The study revealed the basis of its use as folk medicine against various diseases due to the presence of these phytochemicals as bioactive compound. So, the plant extract can be utilized for further investigations.

\section{ACKNOWLEDGEMENT}

The authors wish to acknowledge Dr. Chawngthanliana, Director, Regional Institute of Paramedical and Nursing Sciences, and Dr. H. Lalhlenmawia, Head of Department of Pharmacy, RIPANS, for the facilities provided to complete this research work.

\section{REFERENCES}

Abena, A.A., Ouamba, J.M., Keita, A. (1996). Antiinflammatory, analgesic and antipyretic activities of essential oil of Agereatum conyzoides. Phytoter. Res. 10, S164-S165.
Achola, K.J., Munenge, R.W., Mwaura, A.M. (1994). Pharmacological properties of root and aerial parts extracts of Ageratum conyzoides on isolated ileum and Heart. Fitoterapia. 56, 103-109.

Afify, Ael-M, El-Beltagi, H.S., El-Salam, S.M., Omran, A.A. (2012). Biochemical changes in phenols, flavonoids, tannins, vitamin $E, \beta$-carotene and antioxidant activity during soaking of three white sorghum varieties. Asian Pac J Trop Biomed. 2(3), 203-209.

Alabri, T.H.A., Musalami, A.H.S.A., Hossain, M.A., AlRiyami, A.M.W.Q. (2014). Comparative study of phytochemical screening, antioxidant and antimicrobial capacities of fresh and dry leaves crude plant extracts of Datura metel L. J King Saud Univ Sci. 26, 237-243.

Amadi, B.A., Duru, M.K.C., Agomuo, E.N. (2012). Chemical profiles of leaf, stem, root and flower of Ageratum conyzoides. Asian J. Plant Sci. Res. 2, 428-432.

Amal, M.M.N., Sami, A.K., Marcel, K., Reto, B., Wai, E.A., Thomas, J.S. (2010). The antiprotozoal activity methylated flavonoids from Ageratum conyzoides L. J. Ethnopharmacol. 129, 127-130.

Aziz, M.A. (2015). Qualitative phytochemical screening and evaluation of anti-inflammatory, analgesic and antipyretic activities of Microcos paniculata barks and fruits. J. Integr Med. 13(3), 173-184.

Borthakur, N., Baruah, A.K.S. (1987). Search for precocenes in Ageratum conyzoides Linn. of North-East India. J. Indian Chem. Soc. 64, 580-581.

Breslin, A. (2017). The Chemical Composition of Green Plants. Sciencing, Leaf Group Ltd.

Bearth, A.C., Siegrist, M. (2014). The consumer's perception of artificial food additives: influences on acceptance, risk and benefit perceptions. Food Qual Preference 38, 14-23.

Brain, F.H., Thomas-Bigger, J., Goodman, G. (1985). The Pharmacological Basis of Therapeutics. Macmillan, New York NY, USA, p. 7.

Durodola, J.J. (1977). Antibacterial property of crude extracts from herbal wound healing remedy - Ageratum conyzoides. Planta Med. 32, 388-390.

FazelShamsa, HamidrezaMonsef, RouhollahGhamooshi, MohammadrezaVerdian-rizi. (2008). Spectrophotometric determination of total alkaloids in some Iranian medicinal plants. Thai J. Pharm Sci. 32, 17-20.

Ghasemzadeh, A. Jaafar, H.Z.E., Rahmat, A. (2010). Antioxidant activities, total phenolics and flavonoids content in two varieties of Malaysia Young Ginger (Zingiber officinale Roscoe). Molecules. 15, 43244333.

Gbolade, A.A., Onayade, O.A. Ayinde, B.A. (1999). Insecticidal activity of Ageratum conyzoides L. volatile oil against Callosobruchus chinensis $\mathrm{F}$ in seed treatment and fumigation laboratory tests. Insect Science and its Application. 19, 237.

Hajlaoui, H. T., Noumi N., Snoussi E., Fallah M., Ksouri H., Bakhrouf R.A. (2009). Biological activities of the essential oils and methanolic extract of tow cultivated 
mint species (Mentha longifolia and Mentha pulegium) used in the Tunisian folkloric medicine. World J. Microbiol. Biotechnol. 25, 2227-2238.

Iwu, M.M. (2000). Food for Medicine: Dietary Plants and Masticatories as Sources of Biologically Active Substances. University of Ife, Ife Press, Nigeria, pp. 303310.

Kabera, J.N., Semana, E., Mussa, A.R., He, X. (2014). Plant secondary metabolites: Biosynthesis, classification, function and pharmacological properties. Journal of Pharmacy and Pharmacology. 2, 377-392.

Marks, M. K., Nwachuku, A. C. (1986). Seed-bank characteristics in a group of tropical weeds. Weed Research, 26(3), 151-158.

Marinova, D., Ribarova, F., Atanassova, M. (2005). Total phenolics and total flavonoids in Bulgarian Fruits and Vegetables. J University Chem Technol M etallurgy. 40 (3), 255-260.

Miean, K.H., Mohamed, S. (2001). Flavonoid (myricetin, quercetin, kaempferol, luteolin, and apigenin) content of edible tropical plants. J Agric Food Chem. 49 (6), 3106-12.

Oliveira, F. Akisue, M.K., Garcia, L.O. (1993). Caracterizacao farmacognostica da droga edo extrato fluido de menstrato, Ageratum conyzoides L. Lecta. 11, 63-100.

Prince, L. Prabakaram, P. (2011). Chemical profile analysis of medicinal plants. Asian J. Plant. Sci. 20, 1-8.

Rao, T.M., Rao, B.G., Rao, Y.V. (2012). Antioxidant activity of Spilanthes acmella extracts. Int J. Phytopharmacol. $3(2), 216-220$.
Rasool, N., Rizwan, K. Zubair, M. Naveed, K.U.R., Imran, I., Ahmed, V.U. (2011). Antioxidant potential of different extracts and fractions of Catharanthus roseus shoots. Int. J. Phytomed. 1(3), 108-114.

Santhi, K., Sengottuvel, R. (2016). Qualitative and quantitative phytochemical analysis of Moringa concanensis Nimmo. Int. J. Curr. M icrobiol. App. Sci. 5(1), 633-640.

Shamsa, F., Monsef, H., Ghamooshi, R., Verdian-rizi, M. (2008). Spectrophotometric determination of total alkaloids in some Iranian medicinal plants. Thai J Pharm Sci. 32, 17-20.

Singhh, H., Bhushan, S., Arora, R., Buttar, H.S., Arora, S., Singh, B. (2017). Alternative treatment strategies for neuropathic pain: role of Indian medicinal plants and compounds of plant origin: a review. Biomed Pharmacother. 92, 634-650.

Mallikarjuna, T.R., Ganga, T.R., Venkateswara, Y.R. (2012). Antioxidant activity of Spilanthes acmella extracts. Int J Phytopharmacol. 3(2), 216-220.

Thakur, A.V., Ambwani, S., Ambwani, T.K. (2018). Preliminary phytochemical screening and GC-MS analysis of leaf extract of Acacia catechu (I.f.) wild. Int J Herbal Med. 6(2), 81-85.

Varadarajan, P., Rathinaswamy, G., and Asirvatahm, D. (2008). Antimicrobial properties and phytochemical constituents of Rheo discolor. Ethnobotanical leaflet 12, 841-845.

Yadav, R.N.S., Agarwala, M. (2011). Phytochemical analysis of some medicinal plants. J. Phytol. 3(12), 10-14. 